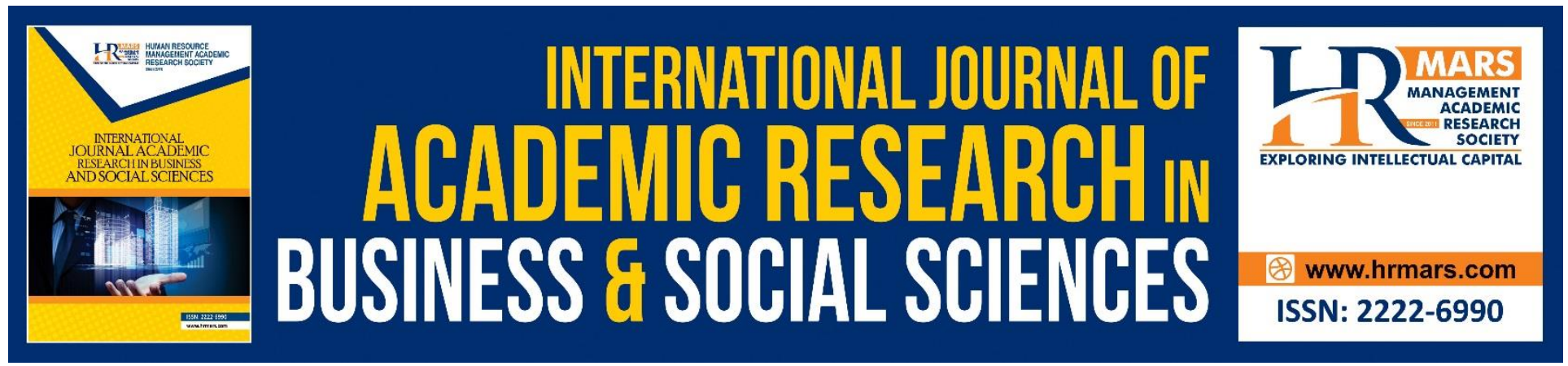

\title{
Fraudulent Financial Reporting and Impression Management: An Examination of Corporate Accounting Narratives
}

Hartini Jaafar, Hazianti Abdul Halim, Rosmini Ismail, Anis Suriati Ahmad

To Link this Article: http://dx.doi.org/10.6007/IJARBSS/v8-i10/4782

DOI: $10.6007 /$ IJARBSS/v8-i10/4782

Received: 18 Sept 2018, Revised: 17 Oct 2018, Accepted: 28 Oct 2018

Published Online: 06 Nov 2018

In-Text Citation: (Jaafar, Halim, Ismail, \& Ahmad, 2018)

To Cite this Article: Jaafar, H., Halim, H. A., Ismail, R., \& Ahmad, A. S. (2018). Fraudulent Financial Reporting and Impression Management: An Examination of Corporate Accounting Narratives. International Journal of Academic Research in Business and Social Sciences, 8(10), 824-837.

Copyright: (C) 2018 The Author(s)

Published by Human Resource Management Academic Research Society (www.hrmars.com)

This article is published under the Creative Commons Attribution (CC BY 4.0) license. Anyone may reproduce, distribute, translate and create derivative works of this article (for both commercial and non-commercial purposes), subject to full attribution to the original publication and authors. The full terms of this license may be seen

at: http://creativecommons.org/licences/by/4.0/legalcode

Vol. 8, No. 10, 2018, Pg. 824 - 837

http://hrmars.com/index.php/pages/detail/IJARBSS

JOURNAL HOMEPAGE

Full Terms \& Conditions of access and use can be found at http://hrmars.com/index.php/pages/detail/publication-ethics 


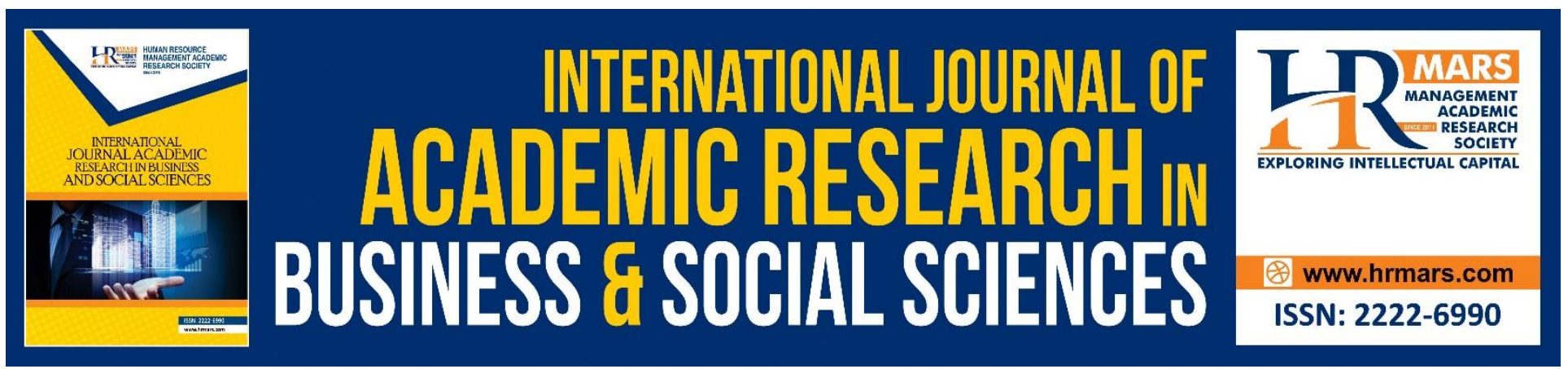

\title{
Fraudulent Financial Reporting and Impression Management: An Examination of Corporate Accounting Narratives
}

\author{
Hartini Jaafar, Hazianti Abdul Halim, Rosmini Ismail, Anis Suriati \\ Ahmad
}

Faculty of Management and Economics, Universiti Pendidikan Sultan Idris, Malaysia

\begin{abstract}
The purpose of this study is to examine the motivation for impression management in the presentation of corporate accounting narratives among Malaysian public listed firms. A matched sample of 80 fraudulent financial reporting firms and non-fraudulent financial reporting firms is utilised in this study. Content analysis of impression management technique of enhancement and retrospective sense-making in the use of corporate accounting narratives is performed. The findings indicate that the sample firms use impression management to portray an image consistent with the overall reading of the annual report, despite favourable with organisational outcomes (impression management by means of enhancement) and to retrospectively provide explanations of organisational outcomes and events (retrospective sense-making). This study adds to and extends the body of knowledge in understanding the relationship between corporate narrative reports and impression management in a different context of organisational outcomes unique to Malaysian setting.
\end{abstract}

Keywords: Fraudulent Financial Reporting, Impression Management

\section{Introduction}

Malaysia aims to become a high-income status country by the year 2020 and combating corruption has been identified as one of the key challenges in this national aspiration. Financial reporting is considered as an essential link in the accountability chain and of particular importance when it comes to combating corruption (Transparency International, 2009). This is primarily because of its role in creating an attractive business environment to attract international and long-term capital. Malaysia aspires to have a vibrant and liquid capital market that attracts quality listings and investors. By 2020, market capitalisation of Bursa Malaysia is expected to grow from RM1.0 trillion in 2010 to RM3.9 trillion by 2020 (Economic Transformation Programme Handbook, 2012) and this requires a more transparent and quality financial reporting. 
However, in the Fraud, Bribery and Corruption Survey 2013 conducted by KPMG Malaysia, over $83 \%$ of the respondents acknowledged that fraud was a major and inevitable problem of conducting business in Malaysia (KPMG, 2014). Further, in PwC's 2014 Global Economic Crime Survey, financial reporting fraud has been found to be one of the major crimes that has always been on the list of economic crime and is cited repeatedly by more than $20 \%$ of the respondents since 2005 (PwC, 2014). Another interesting finding of the survey is that the Asia Pacific region reports $21 \%$ financial reporting fraud, placing it at the third place after Africa and the Middle East (35\%) and North America (23\%). Meanwhile in its more recent 2016's survey, $18 \%$ of the respondents indicate their experience with financial reporting fraud which is also considered as one of the high impact crimes. Despite the slight decrease, there is however a growing concern among companies that detection and control programmes are not keeping up with the pace of change in economic crime, while financial cost of each fraud keeps on increasing. Since financial statements are regarded as fundamental barometer of a business, any accounting fraud (including misleading or falsely prepared financial statements) can lead banks, lessors, vendors and investors into risky or misguided investment decisions. Due to the ubiquitous use of financial reports in business operation, this type of fraud can impact a variety of business processes.

Impression management, a strand of the financial disclosure literature that examines managers' attempts to manage the interpretation of financial reports (Neu, 1991), is a concept that can be employed to explain the connection between fraudulent financial reporting and the manipulation concept of financial information. Impression management happens when management selects the information to display and presents that information in a manner that distorts readers' perceptions by enhancing corporate achievements. It occurs predominantly in less regulated narrative and graphical accounting disclosures which focus on interpreting financial outcomes (Brennan et al., 2013).

It can be argued that in the case of possible fraudulent financial reporting, firms facing certain financial predicaments may employ impression management as a tool to manipulate the presentation of financial statements. This is motivated by the assumption that managers use such tools to obfuscate corporate performance, especially negative performance. Specifically, it is argued in this study that firms with greater tendency to involve in fraudulent financial activities have greater motivation to use accounting narratives presented in their annual reports as impression management strategy. Further, in comparison to previous studies that rely on audited financial information (Nelson, 2012; Khairul Anuar and Wan Adibah, 2014; Hawariah et al., 2014; Hosseini Nia, 2015; Aghghaleh, et al., 2014; Mohamed Yusof et al., 2015), this study adds to the understanding of fraudulent financial reporting activities using unaudited information in the form of accounting narratives by incorporating impression management concept. Manipulation of financial statements especially the unaudited information to obfuscate negative performance leads to firms not reporting a true and fair view of their financial position, resulting in misallocation of resources by potential investors. Hence, this study seeks to investigate the motivations for impression management between fraudulent financial reporting firms and non-fraudulent financial reporting firms. 


\section{Literature Review}

The Association of Certified Fraud Examiners (ACFE) defines fraud as "the intentional, deliberate, misstatement or omission of material facts, or accounting data to mislead and, when considered with all the information made available, would cause the reader to alter his or her judgement in making a decision, usually with regards to investments" (ACFE, 2008). This definition is important to be highlighted because it infers that investors' decision-making process relies on the provided financial statements. Thus, it can be seen that fraudulent financial reporting is related to the reliability aspect of financial quality since it concerns the issue of truthfulness of the quality of earnings disclosed (Akers et al., 2007). According to Squires (2003) economic crime and fraud does not show a clear sign thus forensic accountants have to look beyond all the figures to examine the real situation. This is consistent with Ogoun and Obara (2013) who argue that a major obstacle to addressing the problem of financial reporting fraud promptly is related to the difficulty of identifying the fraud soon after its occurrence. Because it is often a management fraud, it is well hidden from auditors, investors and other stakeholders and it is usually only discovered by chance or once the company is in financial difficulty which may result in a takeover or insolvency (Baucus and Near, 1991). Nonetheless, any form of corporate fraudulent activities is a serious threat to the business and can lead to large losses to both firms and directors (Zimbelman and Albrecht, 2012). Further, fraudulent financial reporting can reduce the credibility of the accounting profession particularly in the preparation and communication of financial statement.

Meanwhile, the term impression management refers to the process by which individuals attempt to control the impressions of others (Leary and Kowalski, 1990). In the context of corporate financial reporting, impression management occurs when management selects information to display and presents that information to distort readers' perceptions of corporate achievements (Neu, 1991). It can play a role in restoring reputation, image or legitimacy in times of crisis or change, for example during adverse financial performance (Courtis, 2004), corporate scandals (Linsley and Kajüter, 2008), environmental disasters (Hooghiemstra, 2000) and major reorganisation (Odgen and Clarke, 2005). Impression management occurs largely in less regulated narrative accounting disclosures which focus on interpreting financial outcomes (Brennan et al., 2013).

Financial information is frequently communicated through written narratives which are largely qualitative in nature and which are sometimes referred to as 'soft' or unquantified information (Brennan and Merkl-Davies, 2013). The function of accounting narratives in financial reports is to amplify quantified financial information. Most accounting narratives in financial reports are not subject to external audit, which makes it easier for managers to manipulate the information disclosed therein. Therefore, this study attempts to examine whether unaudited accounting narratives are used by fraudulent companies as tools of impression management. This is motivated by the assumption that managers use accounting narratives in the form of difficult-to-read language to obfuscate corporate performance, especially negative performance.

Merkl-Davies et al. (2011) consider impression management from two different perspectives; (i) presenting an inaccurate view of organisational outcomes (self-presentational dissimulation) and/or (ii) as presenting an accurate, albeit favourable, view of organisational outcomes (enhancement). Specifically, self-presentational dissimulation suggests creating an impression at variance with the overall reading of the annual report whereas impression management by way of enhancement 
entails creating an impression consistent with the overall reading of the annual report. Apart from that, in their study Merkl-Davies et al. (2011) also postulate that corporate narratives not only can be used as impression management tool, but also to retrospectively provide a frame of organisational outcomes (retrospective sense-making).

Merkl-Davies et al. (2011) adapt a content analysis approach based on the linguistic style associated with self-presentational dissimulation developed by Newman et al. (2003). They argue that prior studies in psychology (such as DePaulo et al., 2003; Newman et al., 2003; Zhou et al., 2004) suggest that the texts of individuals who engage in deception exhibit the following characteristics; shorter, contain fewer self-references, contain fewer references to others, contain fewer positive emotion words, contain more negative emotion words and contain fewer words indicative of cognitive complexity. Thus, based on these specific characteristics, proxies for self-presentational dissimulation in corporate reporting is developed. Further, they also argue that these proxies are also useful as indicators of managerial enhancement of positive organisational outcomes or managerial retrospective sense-making.

Negative organisational outcomes can motivate firms to engage in impression management. Hence, it can be predicted that firms with negative organisational outcomes such as those identified as fraudulent financial reporting firms are more likely to present a public image of organisational performance inconsistent with the managerial view of actual organisational performance than firms with positive organisational outcomes (non-fraudulent financial reporting firms). Nevertheless, firms may also use corporate accounting narratives to present an accurate that is consistent with an overall reading of the annual report, but favourable, view of organisational outcomes (enhancement of positive organisational outcome). Thus, we expect firms to emphasise positive organisational outcomes, regardless of their financial condition. This hypothesis is expressed in null form.

$H_{01}$ : There is no significant difference in impression management by means of enhancement between fraudulent financial reporting firms and non-fraudulent financial reporting firms.

Alternatively, firms may also need to retrospectively provide explanations of organisational outcomes and events, an activity known as retrospective sense-making, a condition viewed as an ex post accountability in corporate reporting. Aerts (2005) states that retrospective sense-making is a condition where managers engage in "ex post explanations or restatements of organizational outcomes and events" (p. 497) while Crossley (2000) mentions that it is an activity where managers draw together "a series of events in order that they make sense in relation to one another" (p. 535). Similarly, firms are expected to emphasise retrospective sense-making, regardless of their financial condition. Hence, the hypothesis is expressed as follows:

$\mathrm{H}_{02}$ : There is no significant difference in retrospective sense-making activities between fraudulent financial reporting firms and non-fraudulent financial reporting firms.

\section{Research Methodology}

Sample firms are selected from the list of public listed companies on the Main Board of Bursa Malaysia between the years 2011 to 2016 . The six-year period is chosen preliminarily to ensure data availability and sufficiency. List of firms potentially involved in fraudulent reporting are obtained from 
Bursa Malaysia media centre. The list summarises firms according to the offences made against the Listing Requirements of Bursa Malaysia Securities Bhd, most of which are reporting material misstatements in the financial reports. The procedure yields a total of 86 firms for the preliminary sample. Firms from the financial and insurance and real estate investment trusts (REITs) sectors are excluded from the final sample due to different accounting policies and financial reporting requirements. In addition, firms with missing annual reports are excluded from the sample, leaving 40 firms in the fraudulent financial reporting pool.

Previous studies that examine fraudulent and non-fraudulent financial reporting firms have employed a maximum ratio of 2.5 on the sample size (Aghghaleh et al., 2014; Hawariah et al., 2014; Mohamed Yusof et al., 2015). In this study, each fraudulent firm is matched to a corresponding nonfraudulent firm on the ratio of 1:1 on the basis of size (total assets), industry and financial year, consistent with Hawariah et al. (2014). This leaves a final sample of 80 firms for both fraudulent and non-fraudulent financial reporting firms. Fraudulent financial reporting firms has an average of RM213,923,352 in total assets compared to RM212,257,061 in total assets for the matched nonfraudulent firms. An independent sample t-test indicates that there is no significant difference in the size of the matched-pair samples $(p=0.982)$ and, therefore, both groups of sample firms have comparable size, operated in the same industry and same financial year.

In this study, content analysis of the narrative disclosures in the annual reports or more specifically the Chairman Statements are employed. This particular section of the annual report is relatively short, thus making it especially suitable for content analysis due to the labour-intensive process of collecting, preparing and analysing the textual data. Further, it has been a tried and tested medium for the investigation of impression management in accounting narratives. Analysis of impression management techniques in this study is based on the methodology introduced and refined by MerklDavies et al. (2011). First, the annual reports are obtained in pdf format. Next, photographs (and the captions), images, charts, graphs, forms of address (Dear Shareholders) and greetings (Yours faithfully) are removed from the Chairmen's Statements and converted into text format. These texts are then analysed based on six linguistic indicators associated with impression management.

A computerised text analysis program, developed by psychologists for the purpose of analysing linguistic style; Linguistic Inquiry and Word Count (LIWC), is used to measure the reporting bias in the Chairman Statement of sample firms. LIWC is a transparent text analysis program that analyses written text on a word-by-word basis and counts words in psychologically meaningful categories (Tausczik and Pennebaker, 2010). The content analysis approach in corporate reporting introduced by Merkl-Davies et al. (2011) is based on the linguistic style developed by Newman et al. (2003). From the linguistic indicators four dimensions are extracted from LIWC which include the following:

(i) Word count (LIWC: Log word count)

(ii) Positive emotion words (LIWC: positive emotions)

(iii) Negative emotion words (LIWC: negative emotions)

(iv) Cognitive complexity (LIWC: overall cognitive words) 
The skewness and kurtosis of the data is between -2 and +2 which are considered to provide evidence for normal univariate distribution (George and Mallery, 2010). Nonetheless, further tests using Kolmogorov-Smirnov and Shapiro-Wilk tests of normality suggests that the data significantly deviate from a normal distribution (Sig. value < 0.05). Therefore, log word count is used rather than the raw word count. Following Merkl-Davies et al. (2011), custom dictionaries for the two remaining linguistic indicators are used which are:

(v) Self-reference (contains three-word categories - first person plural pronouns i.e. we, us, ours, ourselves, the Group and the respective company name)

(vi) Reference to others (contains four-word categories - industry, sector, competitor and rival)

If firms use accounting narratives in annual reports to enhance positive organisational outcomes (or obfuscate negative organisational outcomes) regardless of their financial condition, there should be no significant difference in the use of positive key words and negative key words between these two types of firms (Smith and Taffler, 2000; Rutherford, 2005). LIWC content categories of positive and negative emotion words which capture words with positive and negative connotations, respectively are used to find support for $\mathrm{H}_{01}$. Sense-making on the other hand, is assumed to manifest itself in an increase in document length and cognitive complexity (Merkl-Davies et al., 2011). Further, Bloomfield (2008) also uses document length as a proxy for cognitive complexity and argues that word and sentence length can be interpreted as indicators of the complexity of news to be described rather than only as a means of obfuscation through reading difficulty. Negative organisational outcomes particularly require more complex and detailed explanations than positive organisational outcomes. Based on these arguments, log of total word count in text and LIWC content category of cognitive complexity are used to test for $\mathrm{H}_{02}$.

\section{Research Findings}

Table 1 provides the descriptive statistics for the six linguistic of the sample firms and it can be seen that the mean for number of word counts for the whole firms used in the sample is 1079.81 , with a minimum of 381.00 and maximum of 2742.00 word counts used in the Chairman Statements. These minimum and maximum word counts both come from the non-fraudulent financial reporting group. Meanwhile, the minimum and maximum word counts (results not tabulated) for the fraudulent financial reporting group are found to be 413.00 and 2319.00 , respectively. This is consistent with DePaulo et al. (2003) who argue that among the linguistic characteristics of deception is shorter text for it provides less details in the accounts of events. 
INTERNATIONAL JOURNAL OF ACADEMIC RESEARCH IN BUSINESS AND SOCIAL SCIENCES

Vol. 8, No. 10, Oct. 2018, E-ISSN: 2222-6990 @ 2018 HRMARS

Table 1: Descriptive Statistics for Linguistic Indicators of Impression Management

\begin{tabular}{lcccccc}
\hline Variable & $\mathbf{n}$ & Mean & Median & SD & Min & Max \\
& & & & & & \\
\hline $\begin{array}{l}\text { Word count (number of } \\
\text { words) }\end{array}$ & 80 & 1079.81 & 982.00 & 568.93 & 381.00 & 2742.00 \\
Positive emotion words (\%) & 80 & 3.54 & 3.43 & 0.99 & 1.85 & 6.62 \\
Negative emotion words (\%) & 80 & 0.61 & 0.50 & 0.50 & 0.00 & 2.62 \\
Cognitive complexity (\%) & 80 & 3.03 & 2.99 & 0.65 & 1.66 & 4.88 \\
Reference to self (\%) & 80 & 4.17 & 3.68 & 3.42 & 1.42 & 31.66 \\
Reference to others (\%) & 80 & 0.33 & 0.26 & 0.34 & 0.00 & 1.89 \\
& & & & & & \\
\hline
\end{tabular}

The descriptive statistics also show substantial differences in the mean values between positive and negative emotion words (3.54\%) and negative emotion words (0.61\%). This suggests that, on average, the Chairmen Statements accounted for in the sample tend to contain four times as many positive emotion words rather than negative emotion words. This in a way could imply that such corporate narrative could contain financial reporting bias with firms introducing positive bias into corporate narrative documents. Nonetheless, the findings also indicate that the mean score for positive (negative) emotion words of fraudulent financial reporting firms are 3.50 (0.62) compared to nonfraudulent financial reporting firms that have the mean score of 3.60 (0.61). Such lower (higher) mean scores are contradictory to Newman et al. (2003) argument that increased use of emotion words (both positive and negative) as indicator for deception.

Further, the results for cognitive complexity indicator show that the overall mean score is 3.03 while the minimum and maximum values are 1.66 and 4.88 respectively. Newman et al. (2003) posit that in order to avoid complex stories, deceptive texts usually contain fewer words indicative of cognitive complexity. However, further analysis (results not tabulated) is inconsistent with this argument, with fraudulent financial reporting firms exhibiting higher mean value for cognitive complexity (3.08) compared to their non-fraudulent financial reporting counterparts with mean value of 2.98.

Table 1 also shows that the mean for self-references and references to other are 4.17 and 0.33 , respectively. Both the minimum and maximum values for self-references come from the nonfraudulent financial reporting group while the mean score for this group is also found to be higher (4.28) compared to the fraudulent financial reporting group (4.05). This finding is consistent with firms engaged in deception to avoid using self-referencing words to distance themselves from their stories and avoid taking responsibilities for their behaviour (Newman et al., 2003).

A Mann-Whitney $U$ test is conducted to compare the differences between the two sample groups, fraudulent financial reporting firms and non-fraudulent financial reporting firms. It is hypothesised in $\mathrm{H}_{01}$ that there is no significant difference in impression management by means of enhancement between fraudulent financial reporting firms and non-fraudulent financial reporting firms. 
INTERNATIONAL JOURNAL OF ACADEMIC RESEARCH IN BUSINESS AND SOCIAL SCIENCES

Vol. 8, No. 10, Oct. 2018, E-ISSN: 2222-6990 @ 2018 HRMARS

Table 2: Test of $\mathrm{H}_{01}$ Impression Management by Means of Enhancement

\begin{tabular}{lccc}
\hline Descriptive Statistics & $\begin{array}{c}\text { Fraudulent } \\
\text { Financial } \\
\text { Reporting Firms } \\
(\mathrm{n}=40)\end{array}$ & $\begin{array}{c}\text { Non-Fraudulent } \\
\text { Financial } \\
\text { Reporting Firms } \\
(\mathrm{n}=40)\end{array}$ & $\begin{array}{c}U \text { statistics } \\
\text { (p-value) }\end{array}$ \\
\hline Mean of positive emotion words & 3.50 & 3.58 & 733.00 \\
SD & 1.03 & 0.96 & $(0.519)$ \\
Median of positive emotion words & 3.36 & 3.48 & \\
Minimum of positive emotion & 1.88 & 1.85 & \\
words & & 6.08 & \\
Maximum of positive emotion & 6.62 & 0.61 & \\
words & 0.62 & $0.273)$ \\
Mean of negative emotion words & 0.39 & 0.59 & \\
SD & 0.55 & 0.00 & \\
Median of negative emotion words & 0.00 & 2.62 & \\
Minimum of negative emotion & 1.41 & & \\
words & & & \\
Maximum of negative emotion & & & \\
words & & &
\end{tabular}

The results in Table 2 suggest that there is no significant difference in terms of the positive emotion words used by fraudulent financial reporting firms compared to their counterpart $(U=733.00, p=$ 0.519). Similarly, no significant difference can be observed between the two groups for the use of negative emotion words $(U=686.00, p=0.273)$. However, for both groups of firms, mean scores for positive emotion words are found to be substantially higher than the mean scores for negative emotion words, suggesting firms' tendency to associate themselves with more favourable outcomes. Since impression management by means of enhancement in their corporate accounting narratives is represented by both positive emotion and negative emotion words used by firms, the findings fail to reject $\mathrm{H}_{01}$. This implies that firms, regardless of their financial position, may use corporate annual reports as impression management tool by way of enhancement to present an accurate, despite favourable, view of organisational outcomes.

$\mathrm{H}_{02}$ posits that as an ex post accountability in corporate reporting, firms may need to retrospectively provide explanations of organisational outcomes and events regardless of their financial position. The findings as illustrated in Table 3 suggest that there is no significant difference between fraudulent and non-fraudulent financial reporting firms in terms of the length of words counts used in the Chairmen Statements $(U=707.00, p=0.371)$. Further, the results also indicate that no significant difference can be found in terms of the amount of cognitive complexity presented in the same document across these two groups of firms $(U=764.50, p=0.733)$. Based on these proxies for 
INTERNATIONAL JOURNAL OF ACADEMIC RESEARCH IN BUSINESS AND SOCIAL SCIENCES

Vol. 8, No. 10, Oct. 2018, E-ISSN: 2222-6990 ㄷ 2018 HRMARS

retrospective sense-making, the evidence fails to reject $\mathrm{H}_{02}$. This provides support for the argument that firms may use corporate annual reports to retrospectively provide an account of past events.

Table 3: Test of $\mathrm{H}_{02}$ Retrospective Sense-Making

\begin{tabular}{lccc}
\hline Descriptive Statistics & $\begin{array}{c}\text { Fraudulent } \\
\text { Financial } \\
\text { Reporting } \\
\text { Firms } \\
(\mathrm{n}=40)\end{array}$ & $\begin{array}{c}\text { Non-Fraudulent } \\
\text { Financial } \\
\text { Reporting Firms } \\
(\mathrm{n}=40)\end{array}$ & $\begin{array}{c}\text { U statistics } \\
\text { ( } p \text {-value) }\end{array}$ \\
\hline $\begin{array}{l}\text { Mean of word count (natural } \\
\text { log) }\end{array}$ & 2.96 & 3.00 & 707.00 \\
SD & 0.18 & 0.24 & $(0.371)$ \\
$\begin{array}{l}\text { Median of word count (natural } \\
\text { log) }\end{array}$ & 2.95 & 3.00 & \\
$\begin{array}{l}\text { Minimum of word count } \\
\text { (natural log) }\end{array}$ & 2.62 & 2.58 & \\
$\begin{array}{l}\text { Maximum of word count } \\
\text { (natural log) }\end{array}$ & 3.37 & 3.44 & \\
$\begin{array}{l}\text { Mean of cognitive complexity } \\
\text { SD }\end{array}$ & 3.08 & 2.98 & 764.50 \\
$\begin{array}{l}\text { Median of cognitive } \\
\text { complexity } \\
\text { Minimum of cognitive }\end{array}$ & 0.77 & 0.51 & \\
complexity \\
$\begin{array}{l}\text { Maximum of cognitive } \\
\text { complexity }\end{array}$ & 3.02 & 2.95 & \\
\hline & 1.66 & 2.01 & \\
\hline
\end{tabular}

Overall, the findings suggest that firms have the tendency to engage in impression management by means of enhancement and to engage in retrospective sense-making regardless of their financial condition.

\section{Discussion and Conclusion}

In general, the findings of the study provide support for the use of accounting narrative disclosures as impression management tool among Malaysian public listed companies. Nonetheless, in the test of $\mathrm{H01}$, the results indicate that there is no significant difference in impression management by way of enhancement between the two groups. Further, the results also reveal that both groups use more words with positive rather than negative connotations by exhibiting higher mean scores for positive emotion words than negative emotion words. This suggests that firms, regardless of their financial performance have more tendency to use their corporate accounting narratives as impression 
management vehicles by emphasising the best part of themselves to present a favourable view of organisational outcomes.

$\mathrm{H}_{02}$ examines whether there is any significant difference between fraudulent financial reporting firms and non-fraudulent financial reporting firms in terms of retrospective sense-making. The findings provide support for the use of corporate accounting narratives as impression management tool to not only enhance favourable organisational outcomes $\left(\mathrm{H}_{01}\right)$ but to also provide ex post explanations of organisational outcomes and events. Therefore, it can be argued that by putting organisational events in context, firms, regardless of their financial performance are trying to provide explanations of their decisions and actions as a way of making sense of them.

Taken together, the findings provide support for the proposition that firms have the tendency to employ accounting narratives to portray an accurate but favourable image of organisational outcomes, consistent with the overall reading of the annual reports. Further, firms also use accounting narratives to retrospectively provide an account of organisational outcomes as a result of previous managerial actions and events. Fraudulent financial reporting firms and non-fraudulent financial reporting firms are specifically employed in this study to substantially distinguish firm performance, hence their motivations to engage in impression management techniques. By focusing explicitly on the underlying economics of these firms, this study offers greater understanding about the existence or otherwise of an impression management mechanism in the presentation of corporate narrative reports.

Limited empirical research on impression management in Malaysia suggests that more studies are needed to provide more insights into this issue. Thus, future research could examine different firm characteristics to ascertain the trends in the use of corporate accounting narratives as impression management tool. Moreover, there is also a possibility that due to the more restrictive accounting practice following the adoption of Malaysian Financial Reporting Standards (MFRS), firms might rely on other alternatives to communicate quality or to proactively shape shareholders' and stakeholders' perception of organisational outcomes and events (impression management), such as voluntary disclosure in narrative forms. Therefore, future research could be conducted to examine accounting narratives are used as a signalling tool or impression management tool by firms after the adoption of MFRS.

\section{Acknowledgement}

This study was supported by the University Research Grant from Universiti Pendidikan Sultan Idris, Perak, Malaysia.

\section{References}

Aerts, W. (2005). Picking up the pieces: impression management in the retrospective attributional framing of accounting outcomes. Accounting, Organizations and Society, 30 (6), $493-517$. 
INTERNATIONAL JOURNAL OF ACADEMIC RESEARCH IN BUSINESS AND SOCIAL SCIENCES Vol. 8, No. 10, Oct. 2018, E-ISSN: 2222-6990 ㄷ 2018 HRMARS

Aghghaleh, S.F., Takiah, M.I. \& Zakiah, M.M. (2014). Fraud risk factors of fraud triangle and the likelihood of fraud occurrence: Evidence from Malaysia. Information Management and Business Review, 6 (1), 1 - 7.

Akers, M., Giacomino, A. \& Gissel, J. L. (2007). Earnings management and its implications. The CPA Journal, 77 (8), $64-68$.

Association of Certified Fraud Examiners (2008). Fraud examinations and forensic accounting services [online]. Available: http://www.forensicinvspec.com

Baucus, M. S., \& Near, P. J. (1991). Can illegal corporate behavior be predicted? An event history analysis. Academy of Management Journal, 34 (1), 9 - 36.

Bloomfield, R. (2008). Discussion of Annual report readability, current earnings, and earnings persistence'", Journal of Accounting and Economics, 45 (2-3), 248 - 252.

Brennan, N.M. \& Merkl-Davies, D.M. (2013). Accounting narratives and impression management. In Jack, L. Davidson, J. and Craig, R. (2013). The Routledge Companion to Communication in Accounting, Chapter 8, 109-132. London: Routledge

Brennan, N.M., Merkl-Davies, D.M. \& Beelitz, A. (2013). Dialogism in corporate social responsibility communications: Conceptualising verbal interaction between organisations and their audiences. Journal of Business Ethics, 115 (4), 665 - 679.

Courtis, J.K. (2004). Corporate report obfuscation: artefact or phenomenon? British Accounting Review, 36 (3), 291-312.

Crossley, M.L. (2000). Narrative psychology, trauma and the study of self/identity. Theory \& Psychology, 10 (4), $527-546$.

DePaulo, B.M., Lindsay, J.J., Malone, B.E., Muhlenbruck, L., Charleton, K. \& Cooper, H. (2003). Cues to deception. Psychological Bulletin, 129 (1), $74-188$.

Economic Transformation Programme (2012). ETP Handbook Chapter 1 - 13 [online]. Available http://etp.pemandu.gov.my/download centre.aspx

George, D. \& Mallery, M. (2010). SPSS for Windows Step by Step: A Simple Guide and Reference 17.0 Update (10 ed.), Boston: Pearson.

Hawariah, D., Amrizah, K., Zuraidah, M.S. \& Khairun Syafiza, K. (2014). Detecting fraudulent financial reporting through financial statement analysis. Journal of Advanced Management Science, 2 (1), 1722. 
INTERNATIONAL JOURNAL OF ACADEMIC RESEARCH IN BUSINESS AND SOCIAL SCIENCES Vol. 8, No. 10, Oct. 2018, E-ISSN: 2222-6990 ㄷ 2018 HRMARS

Hooghiemstra, R. (2000). Corporate communication and impression management - new perspectives why companies engage in corporate social reporting. Journal of Business Ethics, 27 (1-2), 55-68.

Hosseini Nia, S. (2015). Financial ratios between fraudulent and non-fraudulent firms: Evidence from Tehran Stock Exchange. Journal of Accounting and Taxation, 7(3), 38 - 44.

Khairul Anuar, K. \& Wan Adibah, W.I. (2014). The effects of audit committee attributes on fraudulent financial reporting. Journal of Modern Accounting and Auditing, 10 (5), 507 - 514.

KPMG (2014). KPMG Malaysia Fraud, Bribery and Corruption Survey 2013 [online]. Available: https://www.kpmg.com/MY/en/IssuesAndInsights/ArticlesPublications/Documents/2013/fraudsurvey-report.pdf

Leary, M.R. \& Kowalski, R.M. (1990). Impression management: A literature review and twocomponent model. Psychological Bulletin, 107 (1), 34-47.

Linsley, P. \& Kajüter, P.M. (2008). Restoring reputation and repairing legitimacy: A case study of impression management in response to a major risk event at Allied Irish banks plc. International Journal of Financial Services Management, 39 (1), 65-82.

Merkl-Davies, D.M., Brennan, N.M. \& McLeay, S.J. (2011). Impression management and retrospective sense-making in corporate narratives: A social psychology perspective. Accounting, Auditing and Accountability Journal, 24 (3), 315-344.

Mohamed Yusof, K., Ahmad Khair, A.H. \& Simon, J. (2015). Fraudulent financial reporting: An application of fraud models to Malaysian public listed companies. The Macrotheme Review, 4 (3), 126 $-145$.

Nelson, S.P. (2012). Pre fraud: An empirical in Malaysia. International Journal of Economics and Finance Studies, 4 (1), 143 - 1515.

Neu, D. (1991). Trust, impression management and the auditing profession. Critical Perspectives on Accounting, 2 (4), 295-313.

Newman, M.L., Pennebaker, J.W., Berry, D.S., \& Richards, J.M. (2003). Lying words: Predicting deception from linguistic styles. Personality and Social Psychology Bulletin, 29 (5), 665 - 675.

Odgen, S. \& Clarke, J. (2005). Customer disclosures, impression management and the construction of legitimacy: corporate reports in the UK privatised water industry. Accounting, Auditing and Accountability Journal, 18 (3), 313-345. 
INTERNATIONAL JOURNAL OF ACADEMIC RESEARCH IN BUSINESS AND SOCIAL SCIENCES

Vol. 8, No. 10, Oct. 2018, E-ISSN: 2222-6990 ㄷ 2018 HRMARS

Ogoun, S. \& Obara (2013). Curbing occupational and financial reporting fraud: An alternative paradigm. International Journal of Business and Social Science, 4 (9), $123-132$.

PwC (2014). Economic crime: the danger within [online]. Available:

http://www.pwchk.com/webmedia/doc/635291163026896490 forensic economic crime survey 2014.pdf

Rutherford, B.A. (2005). Genre analysis of corporate annual report narratives: A corpus linguistics based approach. Journal of Business Communication, 42 (4), $324-348$.

Smith, M. \& Taffler, R.J. (2000). The chairman's report: A content analysis of discretionary narrative disclosures. Accounting, Auditing and Accountability Journal, 13 (5), $624-646$.

Squires, D. W. (2003). Problems solved with forensic accounting: A legal perspective. Journal of Forensic Accounting, 4, 311-320.

Tausczik, Y.R. \& Pennebaker, J.W. (2010). The psychological meaning of words: LIWC and computerized text analysis method. Journal of Language and Social Psychology, 29 (1), 24 - 54.

Transparency International (2009). Transparency in Reporting on Anti-Corruption: A report on Corporate Practices [online].

Available

http://www.cism.my/sites/default/files/publications/Transparency\%20in\%20Reporting\%200n\%20 Anti-Corruption\%20-\%20A\%20Report\%200n\%20Corporate\%20Practices.pdf

Zhou, L., Burgoon, J.K., Nunamaker, J.F. Jr. \& Twitchell, D. (2004). Automated linguistic-based cues for detecting deception in text-based asynchronous computer-mediated communication. Group Decision and Negotiation, 13 (1), 81 - 106

Zimbelman, M. \& Albrecht, C. (2012) Forensic Accounting $4^{\text {th }}$ Ed. South-Western: Cengage Learning. 